\title{
Recent advances in role of chromium and its antioxidant combinations in poultry nutrition: A review
}

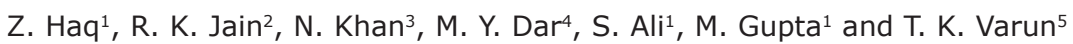

1. Division of Animal Nutrition, Faculty of Veterinary Sciences \& Animal Husbandry, Sher-e-Kashmir University of Agricultural Sciences and Technology of Jammu, Jammu - 181 102, Jammu and Kashmir, India; 2. Department of Animal Nutrition, College of Veterinary Science \& Animal Husbandry, Mhow - 453446, Madhya Pradesh, India; 3. Division of Instructional Livestock Farm Complex, Faculty of Veterinary Sciences \& Animal Husbandry, Sher-e-Kashmir University of Agricultural Sciences and Technology of Jammu, Jammu - 181 102, Jammu and Kashmir, India; 4. Division of Veterinary Anatomy, Faculty of Veterinary Sciences \& Animal Husbandry, Sher-e-Kashmir University of Agricultural Sciences and Technology of Jammu, Jammu - 181 102, Jammu and Kashmir, India; 5. Division of Animal Nutrition, National Dairy Research Institute, Karnal, Haryana, India.

Corresponding author: Z. Haq, e-mail: zulfy11@gmail.com,

RKJ: drrkjainvet@gmail.com, NK: drnazamkhan@yahoo.com, MYD: yousufdar8@gmail.com,

SA: shamim.drlal@gmail.com, MG: mokshtagupta1407@gmail.com, TKV: dr.tkvarun@gmail.com

Received: 30-04-2016, Accepted: 12-09-2016, Published online: 09-12-2016

doi: 10.14202/vetworld.2016.1392-1399 How to cite this article: Haq Z, Jain RK, Khan N, Dar MY, Ali S, Gupta M, Varun TK (2016) Recent advances in role of chromium and its antioxidant combinations in poultry nutrition: A review, Veterinary World, 9(12): 1392-1399.

\begin{abstract}
Poultry is reared in open side houses in most of the tropical countries, which results in huge temperature variation in shed causing stress resulting in increased demand of antioxidant supplementation. Since cooling of poultry houses or environment control is very expensive, thus methods focused on nutritional modifications appears to be the much logical approach. Stress increases mineral and vitamin mobilization from tissues and their excretion. Effect of some minerals and vitamin supplements such as chromium $(\mathrm{Cr})$ and ascorbic acid to elevate the negative effects of environmental stress is well documented. Cr functions as an antioxidant and its deficiency are said to disrupt carbohydrate and protein metabolism. $\mathrm{Cr}$ has been utilized for weight gain, to improve feed conversion ratio, increase relative organ weight, muscle development, decrease cholesterol, increase high-density lipoprotein cholesterol, and improve nutrient digestion. Therefore, the present review discusses the beneficial aspects of $\mathrm{Cr}$ with its effect in different doses and antioxidant combinations to explore and promote its optimum utilization in poultry nutrition and production.
\end{abstract}

Keywords: antioxidants, chromium, poultry, stress.

\section{Introduction}

Metabolism of glucose in birds is considerably different from mammals as blood glucose concentration is much higher in birds and insulin levels are low [1]. Birds as compared to mammals are considered to be less sensitive to insulin [2] and effect of chromium $(\mathrm{Cr})$ to enhance insulin sensitivity in mammals is well documented [3]. Heat or cold stress increases circulating concentrations of corticosterone in broilers and it is well documented that corticosterone reduces insulin sensitivity in broilers [4]. Poultry is reared in open side houses in most of the tropical countries like India, which results in huge temperature variation in the shed [5] causing stress which results in increased demand of antioxidant supplementation. Since cooling of poultry houses (environment control) is very expensive, thus methods are focused on nutritional modifications [6] like search of new feed additives along with their different

Copyright: Haq, et al. Open Access. This article is distributed under the terms of the Creative Commons Attribution 4.0 International License (http://creativecommons.org/licenses/by/4.0/), which permits unrestricted use, distribution, and reproduction in any medium, provided you give appropriate credit to the original author(s) and the source, provide a link to the Creative Commons license, and indicate if changes were made. The Creative Commons Public Domain Dedication waiver (http://creativecommons.org/ publicdomain/zero/1.0/) applies to the data made available in this article, unless otherwise stated. combinations to increase the performance of birds naturally. Stress increases mineral and vitamin mobilization from tissues and their excretion [7], thus may exacerbate a marginal vitamin and mineral deficiency or an increased mineral and vitamin requirement. It has been reported that the negative effects of environmental stress could be prevented by the use of some minerals and vitamin supplements such as vitamin $\mathrm{C}$ and $\mathrm{Cr}[8,9]$. $\mathrm{Cr}$ is essential for proper insulin action, is required for normal protein, fat, and carbohydrate metabolism, and is acknowledged as a dietary supplement in humans also [10]. Trivalent $\mathrm{Cr}$ is associated with the metabolism of carbohydrates, lipids, and proteins in animals termed as "glucose tolerance factor" since Cr regulates the metabolic action of insulin [11]. However, different $\mathrm{Cr}$ forms, i.e. organic and inorganic have diverse rates of absorption. Organic $\mathrm{Cr}$ (Cr-yeast) has greater biological availability than inorganic $\mathrm{Cr}$. Among inorganic sources, the most common forms of $\mathrm{Cr}$ are the metallic form, $\mathrm{Cr}(0)$, trivalent $\mathrm{Cr}$ (III), and hexavalent $\mathrm{Cr}$ (VI). The hexavalent form is a known toxin, mutagen, and carcinogen $[10,12]$. The availability of inorganic $\mathrm{Cr}$ (e.g., $\mathrm{CrCl}_{3}$ ) is very low, in the range of $0.5-2 \%$, whereas organic $\mathrm{Cr}$ (e.g., $\mathrm{Cr} \mathrm{Pic}$ ) is better, i.e., in the range of $10-25 \%$ [13]. $\mathrm{Cr}$ is said to improve weight gain, feed conversion ratio (FCR), increase relative organ weight, lean muscle 
development, reduce abdominal fat, decrease cholesterol, increase high-density lipoprotein (HDL) cholesterol, improve nutrient digestion, and elevate negative effects of environmental stress [14-21].

Although birds do not require any dietary vitamin source as it can synthesize vitamin C. Pardue and Thaxton [22] reported that particular environmental stressors could alter ascorbic acid utilization or synthesis in poultry. It is well documented that under stress conditions such as low or high environmental temperatures, humidity, and high productive rate ascorbic acid synthesis is inadequate [23]. Poultry cannot synthesize vitamin $\mathrm{E}$; thus, vitamin $\mathrm{E}$ requirements must be met from dietary sources [24] in case of increased demand in stress. Vitamin E is a biological chain-breaking antioxidant that protects cells and tissue from lipoperoxidative damage induced by free radicals [23]. Sahin et al. [24] reported that broilers supplemented with dietary $\mathrm{Cr}$ and vitamin $\mathrm{E}$ significantly alleviated the heat stress related decrease in performance suggesting that additional supplementation into diets may be necessary under stress conditions in growing birds.

The present review discusses the beneficial aspects of $\mathrm{Cr}$ with its effect in different doses and antioxidant combinations to explore and promote its optimum utilization in poultry nutrition and production. So, it will be highly useful for scientists, researchers, veterinary professionals, poultry industry, pharmaceutical industry to enrich their knowledge in promoting $\mathrm{Cr}$, and its antioxidant combination usage.

\section{Feed Intake and Feed Conversion}

A plenty of literature suggests that supplementation of $\mathrm{Cr}$ at different levels and combinations in poultry improved feed intake and efficiency $[16,25]$. Kim et al. [26] revealed that 1600 or $3200 \mathrm{Cr}$ Pic supplementation also improved feed efficiency without affecting feed consumption in broilers. Samanta et al. [27] reported $0.5 \mathrm{mg} / \mathrm{kg}$ of $\mathrm{Cr}$ to improve the feed intake and FCR. Lee et al. [28] conducted two trials to evaluate the effect of $\mathrm{Cr}$ on the performance of broilers and found $\mathrm{Cr}$ supplementation improved feed efficiency in broilers. Holoubek et al. [29] conducted an experiment in cockerels and pullets that received $\mathrm{Cr}$ in form of chromium picolinate (Cr Pic) at a dose $300 \mu \mathrm{g} / \mathrm{kg}$. Results indicated that Cr-supplemented group of cockerels and pullets exhibited similar feed conversion, however, feed consumption per unit gain reduced in Cr-supplemented group. Debski et al. [30] observation revealed a slightly lower (statistically nonsignificant) feed consumption and feed conversion in the group receiving Cr-yeast. Kroliczewska et al. [31] evaluated the effect of $\mathrm{Cr}$-enriched yeast supplementation on performance of broilers and concluded that supplementation of $\mathrm{Cr}$ either at 300 or $500 \mu \mathrm{g} / \mathrm{kg}$ of diet did not affect FCR up to 21 days but supplementation of $500 \mu \mathrm{g} \mathrm{Cr} / \mathrm{kg}$ significantly improved FCR at 22-42 days of age. Furthermore,
FCR of the entire trial (1-42 days of age) was reported higher in $500 \mu \mathrm{g} \mathrm{Cr} / \mathrm{kg}$ diet supplemented group in comparison to $300 \mu \mathrm{g} \mathrm{Cr} / \mathrm{kg}$ diet supplemented group and control diet.

Many studies support $\mathrm{Cr}$ supplementation in poultry diet to improve performance during heat or cold stress $[8,24,32]$. Supplementing $\mathrm{Cr}$ at dose of $1500 \mathrm{ppb}$ to broilers in heat stress showed a positive effect on feed intake and feed efficiency [33]. Some studies have also found a negative effect of $\mathrm{Cr}$ on feed intake and FCR [34]. Amatya et al. [35] reported that supplementation of inorganic $\mathrm{Cr}$ (potassium chromate and $\mathrm{Cr}$ chloride) and organic $\mathrm{Cr}$ (Cr-yeast) at $0.2 \mathrm{mg}$ $\mathrm{Cr} / \mathrm{kg}$ feed significantly improved FCR of broiler birds in the $5^{\text {th }}$ week during summer in comparison to control.

There are studies which support synergistic action of $\mathrm{Cr}$ and other antioxidants during stress conditions, by sparing each other resulting in enhanced performance of birds [14]. Sahin and Sahin [8] evaluated the effect of ascorbic acid $\mathrm{Cr}$ Pic supplementation in laying hens reared under a low ambient temperature $\left(6.2^{\circ} \mathrm{C}\right)$. It was concluded that a combination of $250 \mathrm{mg}$ vitamin $\mathrm{C}$ and $400 \mu \mathrm{g} \mathrm{Cr} / \mathrm{kg}$ of diet gave the best results in terms of feed consumption and FCR. Li et al. [36] conducted a study to evaluate the effect of $\mathrm{Cr}$ Pic acid and vitamin $\mathrm{E}$ alone and in combination on the performance of Cherry Valley ducks and found that $\mathrm{Cr}$ Pic acid and vitamin E supplementation lowered FCR in combination than $\mathrm{Cr}$ alone.

\section{Growth Performance}

$\mathrm{Cr}$ supplementation increases the live weight gain and carcass yield in broilers [16]. According to other studies, $\mathrm{Cr}$ supplementation at different levels in nonruminants increases the carcass quality, weight gain, and organ weight with less carcass fat $[16,37,38]$. Kroliczewska et al. [31] conducted an experiment to evaluate the effect of Cr-yeast on performance of broilers. The experimental data revealed that supplementation of $500 \mu \mathrm{g} / \mathrm{kg} \mathrm{Cr}$ either for 21 or 42 days significantly increased body weight and body weight gain as compared to the dose of $300 \mu \mathrm{g} / \mathrm{kg} \mathrm{Cr}$ and control diet. Amatya et al. [35] conducted study on performance of broiler chickens exposed to natural heat stress during summer. They observed that during $5^{\text {th }}$ week only, the differences with respect to the live weight gain between control group birds and all Cr-supplemented experimental groups were found to be significant. Halder and Ghosh [20] observed that both final live weight and total live weight gain in 40 days improved in Cr-supplemented groups. Essa et al. [18] examined the effect of supplementing different levels of $\mathrm{Cr}$, viz., $0.5,1.0,1.5$, and $2.0 \mathrm{mg} \mathrm{Cr}$-yeast $/ \mathrm{kg}$ diet in broiler chickens. They inferred that live body weight and weight gain significantly increased in broiler supplemented with 0.5 and $1.0 \mathrm{mg}$ Cr-yeast $/ \mathrm{kg}$ feed at end of 3 weeks, whereas, at the end of $5^{\text {th }}$ week, high dosage of Cr-yeast supplementation (1.0, 1.5, and $2.0 \mathrm{mg}$ 
Cr-yeast $/ \mathrm{kg}$ feed) resulted in significantly increased live body weight and weight gain. However, there are studies which suggest that supplementation of $\mathrm{Cr}$ had no effect on body weight gain of broilers $[15,30,39]$. Luciana et al. [40] concluded that Cr tripicolinate had no effect on performance of broilers. Some studies on $\mathrm{Cr}$ at dose rate of $400 \mathrm{ppb} \mathrm{Cr}$-yeast report a negative effect of $\mathrm{Cr}$ on body weight gain [34].

Many studies suggest that $\mathrm{Cr}$ performs better in terms of weight gain and carcass conformation in combination with antioxidants such as ascorbic acid or vitamin E $[6,41,42]$, especially in case of stress conditions such as high or low temperature and humidity. Sahin et al. [17] conducted an experiment to study the effect of combination of $\mathrm{Cr}$ and vitamin $\mathrm{E}$ in cold stressed Japanese quails supplemented with either $400 \mu \mathrm{g}$ of $\mathrm{Cr} / \mathrm{kg}$ of diet (Cr group), $250 \mathrm{mg}$ of $\alpha$-tocopherol-acetate per $\mathrm{kg}$ of diet (vitamin $\mathrm{E}$ group), or $400 \mu \mathrm{g}$ of $\mathrm{Cr}$ plus $250 \mathrm{mg}$ of $\alpha$-tocopherol-acetate per $\mathrm{kg}$ of diet (vitamin E + Cr group). Supplemental $\mathrm{Cr}$ and vitamin $\mathrm{E}$ significantly increased live weight gain, egg production, and improved feed efficiency in cold-stressed laying hens. However, a combination of vitamin $\mathrm{E}$ and $\mathrm{Cr}$, rather than each separately, provided the greatest performance also increased serum vitamin $\mathrm{C}$, vitamin $\mathrm{E}$, and decreased malondialdehyde (MDA) concentrations. Mirfendereski and Jahanian [43] effects of dietary supplementation of Cr-methionine and vitamin $\mathrm{C}$ on performance of broilers and found that Cr-Met supplementation was more effective in improving egg production and FCR that unsupplemented diets. Ipek and Sahan [44] carried out a study to determine the effect of vitamin $\mathrm{E}$ and vitamin $\mathrm{C}$ alone, and in combination, on the performance of Japanese quails reared under heat stress and found that live weight was in chicks on a combination of $240 \mathrm{mg}$ of vitamin E and $240 \mathrm{mg}$ of vitamin C.

\section{Hematological Profile \\ Glucose}

$\mathrm{Cr}$ is biologically active as part of a biomolecule called chromodulin, which is part of an insulin signaling pathway thus affecting carbohydrate and lipid metabolism via the action of insulin [45]. Insulin has been shown to increase the glucose and amino acid uptake into muscle cells thus regulating energy production, muscle tissue deposition, and fat metabolism. In case glucose is not utilized by body cells due to a low insulin level, it gets converted to fat and stored in fat cells. Furthermore, if adequate amino acids cannot enter the cells, muscles cannot be built [46]. Cr is known to enhance insulin sensitivity in mammals and $\mathrm{Cr}$ supplementation has reduced plasma glucose concentrations in broilers $[26,32,47]$.

Bakhiet and Elbadwi [48] on the basis of experimental findings reported that serum glucose values of broiler groups supplemented with inorganic $\mathrm{Cr}(\mathrm{Cr}$ chloride) at the level of $0.2,0.3$, and $0.4 \mathrm{mg} \mathrm{Cr} / \mathrm{kg}$ diet were significantly decreased as compared with control broiler group. Halder and Ghosh [20] observed on experimentation that measurement of serum glucose concentration significantly declined in the experimental broiler groups supplemented with 0.5 and $1 \mathrm{mg} \mathrm{Cr} / \mathrm{kg}$ diet when compared with control group. Patil et al. [49] conducted research and observed that serum glucose concentrations were significantly and gradually reduced among broilers of treatment groups supplemented with organic $\mathrm{Cr}$ in the form of $\mathrm{Cr}$ Pic at level 200, 400, and $600 \mathrm{ppb} / \mathrm{L}$ through water than control. Luma et al. [19] observed that blood glucose of all chicken groups supplemented with $1 \mathrm{mg} \mathrm{Cr} / \mathrm{kg}$ diet from inorganic $\left(\mathrm{CrCl}_{3}\right)$ and organic (Cr-yeast and $\mathrm{Cr}$-pic) were significantly decreased as compared with control group. Aslanian et al. [50] conducted a research to evaluate the effect of $\mathrm{Cr}$ methionine on performance and serum metabolite in growing-finishing male broiler and observed that starter and finisher period supplementation of Cr-Met decreased the blood concentrations of glucose significantly. However, there are some reports which show no effect of $\mathrm{Cr}$ on blood glucose [51].

\section{Serum triglycerides, cholesterol, HDL, and low-den- sity lipoprotein (LDL)}

In recent years, considerable research attention on the utilization of $\mathrm{Cr}$ in broiler diets has been given and several studies on the effects of $\mathrm{Cr}$ on cholesterol level and lipid profile have been published. In general, supplemental $\mathrm{Cr}$ has reduced the fat in serum and carcass as well [24,33]. Moeini et al. [32] concluded that $\mathrm{Cr}$, especially in organic form reduces serum triglycerides and LDL cholesterol but elevates serum HDL cholesterol concentrations in heat-stressed broilers. Kim et al. [52] also reported increased HDL cholesterol, decreased LDL cholesterol, and higher ratios of HDL cholesterol in Cr Pic supplemented broilers. An increase of HDL cholesterol [53] and a decrease in total cholesterol and triglycerides [54] have been observed in humans after $\mathrm{Cr}$ supplementation. In previous studies, the beneficial effects of $\mathrm{Cr}$ on growth and blood parameters have been attributed to chromodulins ability to increase the sensitivity of tissue receptors to insulin [45]. Research studies suggest $\mathrm{Cr}$ involvement in carbohydrate metabolism including glucose uptake, glucose utilization for lipogenesis and glycogen formation $[45,55]$.

Kroliczewska et al. [56] evaluated the effect of $\mathrm{Cr}$ from Cr-yeast on serum lipid profile of broiler chicken. They observed that serum total cholesterol and LDL significantly reduced, whereas serum HDL cholesterol significantly increased due to supplementation of $500 \mu \mathrm{g} \mathrm{Cr} / \mathrm{kg}$ diet in broilers as compared to control. Bakhiet and Elbadwi [48] investigated the effect of dietary supplementation with increasing level at $0,0.2,0.3$, and $0.4 \mathrm{mg} \mathrm{Cr} / \mathrm{kg}$ and found that serum total cholesterol and LDL were significantly lowered in all Cr-supplemented group than control. However, serum HDL was significantly increased 
in all $\mathrm{Cr}$-supplemented groups than control group of chicks of broilers. Haldar and Ghosh [20] observed that serum total cholesterol was significantly lowered in broiler group supplemented with $0.5 \mathrm{mg} / \mathrm{Cr} / \mathrm{kg}$ diet from $\mathrm{Cr}$ tripicolinate when compared with control and $1 \mathrm{mg} \mathrm{Cr} / \mathrm{kg}$ dietary supplemented broiler group. Patil et al. [49] conducted experiment in broilers and result of the experiment indicated that serum lipid profile in terms of total cholesterol and LDL cholesterol was significantly reduced in broiler of Cr-supplemented group, whereas, DHL cholesterol increased significantly. Zha et al. [57] conducted an experiment on broilers and reported that Cr-supplemented at $500 \mu \mathrm{g} / \mathrm{kg}$ diet from $\mathrm{Cr}$ Pic significantly decreased total cholesterol level in thigh muscle as against control. Dhia et al. [21] observed that blood total lipid was significantly lowered in dietary Cr-supplemented. The data on blood total cholesterol showed significant reduction in $\mathrm{Cr}$ (from Cr-yeast) and a trend of reducing serum triglycerides but statistically not important in supplemented group as compared to control. Luma et al. [19] observed that blood total lipid and LDL was reduced in groups which received dietary Cr. Navidshad et al. [58] conducted an experiment and results indicated that the $500 \mu \mathrm{g} / \mathrm{kg}$ level of organic Cr decreased the plasma cholesterol concentration in the finisher phase. The $\mathrm{Cr}$ concentration of 1000 and $500 \mu \mathrm{g} / \mathrm{kg}$ was more effective at grower and finisher phase. Aslanian et al. [50] observed that during starter and finisher phase of broilers, supplementation of $\mathrm{Cr}$ methionine decreased the blood concentrations of cholesterol and LDL, whereas HDL concentration was increased.

Several researches have reported that the combination of vitamin $\mathrm{C}$ and $\mathrm{Cr}$ caused more significant changes in lipid profile of broilers than either vitamin $\mathrm{C}$ or $\mathrm{Cr}$ alone and speculated about the synergistic action of vitamin $\mathrm{C}$ and $\mathrm{Cr}$. It was seen that serum glucose and cholesterol concentrations decreased, whereas protein concentration increased when both dietary vitamin $\mathrm{C}$ also $\mathrm{Cr}$ were supplemented. Increasing concentrations of corticosterone were parallel to increases in serum glucose and cholesterol concentrations [17]. Through increasing the effectiveness of insulin, $\mathrm{Cr}$ also indirectly empowers the ascorbic acid transportation $[59,60]$. In addition to this, $\mathrm{Cr}$ is thought to be essential for activating certain enzymes and for stabilization of proteins and nucleic acids [61-63]. It has been recognized that insulin metabolism influences lipid peroxidation [64]. It is well known that hot climate increases MDA concentration as a lipid peroxidation indicator [65]. Tatli Seven et al. [66] found that plasma MDA level was significantly decreased in vitamin C group compared to the control group. Separately or in combination supplemental vitamin $\mathrm{C}$ and $\mathrm{Cr}$ resulted in a decrease in MDA concentration [67]. It has also been reported that serum glucose and cholesterol decreased, whereas total protein, albumin, globulin, calcium, and phosphorus concentrations increased when dietary $\mathrm{Cr}$,
$\mathrm{Se}$, and vitamin $\mathrm{C}$ singly or in combination were supplemented. Similarly, Kutlu and Forbes [68] reported that vitamin $\mathrm{C}$ supplementation increased plasma protein, whereas blood glucose and cholesterol markedly decreased in heat-stressed broilers. A likely mechanism by which vitamin $\mathrm{C}$ causes a reduction in corticosterone concentration is through inhibitory effect of vitamin C on glucocorticoid synthesis, and it has been postulated that the improved performance of poultry results from a decrease in protein derived glucogenesis [23].

\section{Carcass Characteristics and Meat Lipid Profile}

$\mathrm{Cr}$ is also a cofactor of insulin, promoting insulin activity [69], and enhancing amino acid uptake into muscular cells for protein synthesis [70]. Dietary $\mathrm{Cr}$ supplementation has been reported to have a positive effect on meat quality [35] and carcass traits of broiler chicks in natural [71] or heat stress condition [24]. Lambert and Jacquemin [71] reported insulin inhibits gluconeogenesis and depresses adipocyte lipolysis by reducing the activities of adenylate cyclase and hormone sensitive lipase. Amayta et al. [35] observed an increase of the protein level in muscles of broilers fed a diet supplemented with $\mathrm{Cr}$ in the form of $\mathrm{Cr}$ chloride or Cr-yeast. Samanta et al. [27] reported meat protein accretion improved in broiler fed organic $\mathrm{Cr}$ under heat stress condition. Furthermore, increasing in protein levels in the carcass and liver of broilers given $\mathrm{Cr}$ Pic were observed [26].

Kroliczewska et al. [31] conducted a study to evaluate the effect of Cr-yeast on carcass characteristics in broilers and found that it decreased cholesterol level in muscles. The largest differences were observed in breast muscles in the group fed $500 \mu \mathrm{g} / \mathrm{kg} \mathrm{Cr}$, where the content of cholesterol decreased by approximately $19 \%$. Suksombat and Kanchanatwee [72] reported that supplementation of organic $\mathrm{Cr}$ reduced breast meat fat content and increased breast meat protein content. Total cholesterol and triglycerides were reduced by organic $\mathrm{Cr}$ supplementation. Supplementation with 200 and $400 \mathrm{ppb}$ of both Cr-yeast showed the lowest total cholesterol. Anandhi et al. [15] reported that total cholesterol of breast and thigh muscle were significantly reduced in all treatment groups of broilers supplemented with organic $\mathrm{Cr}$ at level 250, 500, and $750 \mu \mathrm{g} /$ $\mathrm{kg}$ diet as compared to control. Zha et al. [57] reported $\mathrm{Cr}$ Pic significantly decreased total cholesterol level in thigh muscle as against control. Lien et al. [47] reported that liver weight percentage relative to body weight was increased in Cr-supplemented broiler group at level $800 \mathrm{ppb} \mathrm{Cr} / \mathrm{kg}$ diet. Tolmir et al. [73] conducted a research study which revealed that breast muscle yield was significantly increased in organic Cr-supplemented broiler group when compared with inorganic $\mathrm{Cr}$-supplemented and control broiler group. Toghyani et al. [33] observed that dressing percentage significantly increased and abdominal fat significantly decreased in all Cr-supplemented broiler 
groups. Further, they found that liver and heart weight percentage relative to body weight was decreased in Cr-supplemented broiler groups, but there was nonsignificant difference when compared with control group. Tolmir et al. [73] reported that there was a significant increase in breast muscle yield and nonsignificant effect was observed in leg muscle yield of the organic Cr-supplemented group.

Since Cr, vitamin E, and vitamin C (postulated to be antioxidants) have a protective effect on pancreatic tissue against oxidative damage $[23,74]$; they may help pancreas to function properly including secretions of digestive enzymes, thus improving retention of nitrogen and fat metabolism. Thus, it can be suggested that these antioxidants might have a synergistic action to modify the carcass and lipid profile as well. Ali et al. [75] conducted a study on ascorbic acid and observed that dressing yield, breast meat, total meat, and wing meat were higher in supplemented broilers. Idown et al. [76] observed that ascorbic acid reduced up to $10 \%$ cholesterol of biceps femoris muscle and exerted a reduction of $12 \%$ cholesterol of serum on the supplemental dose of $100 \mathrm{ppb}$ ascorbic acid. Chae et al. [77] conducted an experiment to study the effects of incremental levels of vitamin $\mathrm{E}$ on meat quality of broilers and concluded that vitamin $\mathrm{E}$ supplementation at higher levels was found beneficial for increased chicken meat quality. Sahin et al. [17] experiment conducted to evaluate the effects of $\mathrm{Cr} \mathrm{Pic}$ and ascorbic acid supplementation on performance and carcass characteristics of broilers reported that supplementing a combination of vitamin $\mathrm{C}(250 \mathrm{mg} / \mathrm{kg}$ of diet $)$ and $\mathrm{Cr}$ (400 mg Cr/ $\mathrm{kg}$ of diet) may offer a potential protective management practice in preventing heat stress-related depression in performance and carcass characteristics of broiler chickens.

\section{Serum minerals}

Sahin and Onderci [78] reported increased serum concentration of calcium $(\mathrm{Ca})$, phosphorous $(\mathrm{P})$, and potassium $(\mathrm{K})$ and decreased the level of sodium $(\mathrm{Na})$. Uyanik et al. [79] documented that feeding $\mathrm{Cr}$ did not affect serum $\mathrm{Ca}$ and $\mathrm{P}$ but increased magnesium $(\mathrm{Mg})$ concentration at the level of $100 \mathrm{mg} / \mathrm{kg}$ of feed. Sahin and Sahin [24] noted that Cr supplementation in the form of $\mathrm{Cr}$ Pic $(400 \mu \mathrm{g} / \mathrm{kg}$ of diet) improved the retention of minerals and decreased the excretion of $\mathrm{Ca}, \mathrm{P}, \mathrm{Cr}$, nitrogen $(\mathrm{N})$, zinc $(\mathrm{Zn})$, and iron $(\mathrm{Fe})$ in laying hens. Sahin et al. [41] observed that $\mathrm{Cr}$ supplementation reduced the excretion rate of $\mathrm{Zn}$ and $\mathrm{Fe}$ in Japanese quail. According to Ahmed et al. [37], the superior retention of $\mathrm{Zn}$ and copper $(\mathrm{Cu})$ in the body may be due to the supplemental $\mathrm{Cr}$ which might have reduced urinary losses of these elements. Amatya et al. [35] found that $\mathrm{Cu}, \mathrm{Zn}, \mathrm{Fe}$, and manganese $(\mathrm{Mn})$ retention was better when $\mathrm{Cr}$ was supplemented in the feed of broilers in the form of Cr-yeast, whereas Uyanik et al. [41] reported that $20 \mathrm{ppm} \mathrm{CrCl}_{3}$ increased serum $\mathrm{Ca}$ and $\mathrm{Mg}$ in laying hens. Effects of different levels of organic and inorganic $\mathrm{Cr}(\mathrm{Cr}$ chloride and $\mathrm{Cr}$ L-methionine) showed an increase in serum $\mathrm{Cr}$ and $\mathrm{Zn}$ concentrations but decrease in $\mathrm{Cu}$ contents [80]. Dietary Cr Pic and ascorbic acid supplementation showed increased concentrations of $\mathrm{Fe}$, $\mathrm{Zn}, \mathrm{Mn}$, and $\mathrm{Cr}$ in laying hens at a low ambient temperature [24], while Cr Pic and vitamin C supplementation in heat-stressed laying hens increased $\mathrm{Ca}$ and $\mathrm{P}$ concentrations [80].

\section{Cr toxicity}

The hexavalent form of $\mathrm{Cr}$ has toxic effects on birds as it promotes the early aging process, reduces hatching ability and effects liver also [81]. It also causes malformation or fetal death and leads to neural deformities. It has damaging effects on DNA and leads to mutation. It affects the function of gastrointestinal microflora on chronic exposure to high dosages [82]. It has the lethal effects on embryo and causes the defects in the development process leading to early chick mortality. It has the negative effect on chick growth and development [81]. Toxicity can be developed when there will be the excess amount of trace mineral added in the feed of the poultry that may lead to decrease the production parameters such as egg production and defective embryo development along with toxicities [83].

\section{Conclusion}

Dietary $\mathrm{Cr}$ has useful effects on feed consumption, nutrient digestibility, growth, lipid profile, and carcass characteristics. It is an essential mineral element that plays an important role in livestock and poultry nutrition, and recently, it has gained public attention due to its well-established effect on reducing cholesterol level of meat. Cardiovascular diseases such as coronary heart disease and atherosclerosis in humans are the leading cause of death worldwide which are strongly related to dietary intake of cholesterol and saturated fat. Thus, decreasing intake of cholesterol and saturated fats will be a choice of our health conscious society that too without compromising a lot on eating habits of economically growing society. Thus lean meat production through chromium supplementation will be in vogue in future.. Abdominal fat in poultry is considered as waste, and unnecessary wastage of feed energy and $\mathrm{Cr}$ supplementation has very promising response according to various studies conducted. From the above literature, it can be clearly pointed out that $\mathrm{Cr}$ when combined with ascorbic acid has got synergetic action. While in combination with vitamin E such results were not seen. Thus, it can be inferred that $\mathrm{Cr}$ in combination with ascorbic acid offers best results.

\section{Authors' Contributions}

$\mathrm{ZH}$ and RK wrote the introduction, feed intake, feed conversion and Growth Performance. MK, MY 
and SA compiled Hematological Profile, Carcass Characteristics and Meat Lipid Profile. MG and TKV wrote Serum minerals, toxicity and conclusion. All authors read and approved the final manuscript.

\section{Acknowledgments}

The authors are grateful to Division Division of Instructional Livestock Farm Complex, Faculty of Veterinary Sciences and Animal Husbandry, Sher-e-Kashmir University of Agricultural Sciences and Technology of Jammu, FVSc \&AH, SKUAST-J for providing all the necessary facilities to prepare this manuscript.

\section{Competing Interests} interests.

The authors declare that they have no competing

\section{References}

1. Brooks, M.A., Grimes, J.L., Spears, K.E., Krafka, K., Lamptey, A. and Lloyd, J.W. (2016) Chromium propionate in broilers: Effect on insulin sensitivity. Poult. Sci., 1: 1-9.

2. Scanes, C.G. (2009) Perspectives on the endocrinology of poultry growth and metabolism. Gen. Comp. Endocrinol., 163: 24-32.

3. Vincent, J.B. (2001) The bioinorganic chemistry of chromium (III). Polyhedron, 20: 1-26.

4. Zhao, J.P., Lin, H., Jiao, H.C. and Song, Z.G. (2009) Corticosterone suppresses insulin-and NO-stimulated muscle glucose uptake in broiler chickens (Gallus gallus domesticus). Comp. Biochem. Physiol., 149: 448-454.

5. Rajkumar, U., Reddy, M.R., Rao, S.V.R., Radhika, K. and Shanmugam, M. (2011) Evaluation of growth, carcass, immune response and stress parameters in naked neck chicken and their normal siblings under tropical winter and summer temperatures. Asian Aust. J. Anim. Sci., 24(4): 509-516.

6. Attia, K.M., Tawfeek, F.A., Mady, M.S. and Assar, A.H. (2015) Effect of chromium, selenium and vitamin C on productive performance and blood parameters of local strain Dokki in Egypt summer conditions. Egypt. Poult. Sci., 35: 311-329.

7. Siegel, H.S. (1995) Stress, strains and resistance. Br. Poult., 36(1): 3-22.

8. Sahin, N. and Sahin, K. (2001) Optimal dietary concentrations of Vitamin $\mathrm{C}$ and chromium picolinate for alleviating the effect of low ambient temperature $\left(6.2^{\circ} \mathrm{C}\right)$ on egg production, some egg characteristics, and nutrient digestibility in laying hens. Vet. Med. Czech., 46: 229-236.

9. Sahin, K. and Kuçuk, O. (2001) Effects of vitamin C and vitamin $\mathrm{E}$ on performance, digestion of nutrients, and carcass characteristics of Japanese quails reared under chronic heat stress $\left(34^{\circ} \mathrm{C}\right)$. J. Anim. Physiol. Anim. Nutr., 85: $335-342$

10. Chowdhury, S., Pandit, K., Roychowdury, P. and Bhattacharya, B. (2003) Role of chromium in human metabolism, with special reference to type 2 diabetes. JAPI., 51: 701-705.

11. Hamidi, O., Mohammad, C., Hasan, G., Ali, A. and Hassan, M. (2016) Effects of chromium (III) picolinate and chromium (III) picolinate nanoparticles supplementation on growth performance, organs weight and immune function in cyclic heat stressed broiler chickens. Vet. Dergi. Kafkas, 1: $10-16$.

12. NRC. (1997) The Role of Chromium in Animal Nutrition. National Academy Press, Washington, DC.

13. Mertz, W. (1969) Chromium occurrence and function in biological systems. Physiol. Rev., 49: 163-239.

14. Sahin, K., Kucuk, O., Sahin, N. and Ozbey, O. (2001) Effects of dietary chromium picolinate supplementation on egg production, egg quality, and serum concentrations of insulin, corticostrerone and some metabolites of Japanese quails. Nutr. Res., 21(9): 1315-1321.

15. Anandhi, M.R., Viswanathan, K. and Mohan, B. (2006) Dietary inclusion of organic chromium on production and carcass characteristics of broilers. Int. J. Poultr. Sci., 5(9): 880-884.

16. Hossain, S.M., Barreto, S.L. and Silva, C.G. (1998) Growth performance and carcass composition of broilers fed supplemental chromium from chromium yeast. Anim. Feed Sci. Technol., 71: 217-228.

17. Sahin, K., Sahin, N. and Kucuk, O. (2003) Effects of chromium, and ascorbic acid supplementation on growth, carcass traits, serum metabolites, and antioxidant status of broiler chickens reared at a high ambient temperature. Nutr. Res., 23: 225-238.

18. Essa, H.A., Dhia, K.I. and Luma, K.A. (2010) Effect of supplementing different levels of chromium yeast to diet on broiler chickens performance. Int. J. Poult. Sci., 9(4): 376-381.

19. Luma, K.A., Dhia, K.I. and Essa, H.A. (2010) Effect of supplementing different sources of chromium to diet on some physiological traits of broiler chickens. Egypt. Poult. Sci., 30: 397-413.

20. Haldar, S. and Ghosh, T.K. (2008) Chromium as a tool against heat stress. Asian Poult. Mag., 3: 2-5.

21. Dhia, K.I., Essa, H.A. and Luma, K.A. (2010) Effect of supplementing different levels of chromium yeast to diet on broiler chickens on some physiological traits. Pak. J. Nutr., 9(10): 942-949.

22. Pardue, S.L. and Thaxton, J.P. (1984) Evidence of amelioration of steroid mediated immunosuppression by ascorbic acid. Poult. Sci., 63: 1262-1268.

23. McDowell, L.R., editor. (1989) Vitamin A and E. Comparative Aspects to Human Nutrition: Vitamins in Animal Nutrition. Academic Press, London. p93-131.

24. Sahin, K., Sahin, N. and Yaralioglu, S. (2002) Effects of vitamin $\mathrm{C}$ and vitamin $\mathrm{E}$ on lipid peroxidation, blood serum metabolites, and mineral concentrations of laying hens reared at high ambient temperature. Biol. Trace Elem. Res., 85(1): $35-45$

25. Jackson, A.R., Powell, S., Johnston, S., Shelton, J.L., Bidner, T.D., Valdez, F.R. and Southern, L.L. (2008) The effect of chromium propionate on growth performance and carcass traits in broilers. J. Appl. Poult. Res., 17: 476-481.

26. Kim, Y.H., Han, I.K., Shin, I.S., Chae, B.J. and Kang, T.H. (1996) Effect of dietary excessive chromium picolinate on growth performance, nutrient utilizability and serum traits in broiler chicks. Asian Aust. J. Anim. Sci., 9: 349-354.

27. Samanta, S., Haldar, S. and Ghosh, T.K. (2008) Production and carcass traits in broiler chicken given diets supplemented with inorganic trivalent chromium and an organic acid blend. Br. J. Poult. Sci., 49: 155-163.

28. Lee, D.N., Wu, F.Y., Cheng, C.H., Lin, R.S. and Wu, P.C. (2003) Effects of dietary chromium picolinate supplementation on growth performance and immune responses of broilers. Asian Aust. J. Anim. Sci., 16: 227-233.

29. Holoubek, J., Jankovsky, M. and Samek, M. (2000) The effect of chromium picolinate supplementation to diets for chick broilers. Czech J. Anim. Sci., 45(1): 13-17.

30. Debski, B., Zalewski, W., Gralaka, M.A. and Kosla, T. (2004) Chromium-yeast supplementation of chicken broilers in an industrial farming system. J. Trace Elem. Med. Biol., 18: 57-51.

31. Kroliczewska, B., Zawadzki, W., Skiba, T. and Mista, T. (2005) Effect of chromium supplementation on chickens broiler growth and carcass characteristics. Acta Vet. Brno., 74: 543-549. 
32. Moeini, M.M., Bahrami, A., Ghazi, S. and Targhibi, M.R. (2011) The effect of different levels of organic and inorganic chromium supplementation on production performance, carcass traits and some blood parameters of broiler chicken under heat stress condition. Biol. Trace Elem. Res., 144: 715-724.

33. Toghyani, M., Shivazad, M., Gheisari, A.A. and Zarkesh, S.H. (2006) Performance, carcass traits and hematological parameters of heatstressed broiler chicks in response to dietary levels of chromium picolinate. Int. J. Poult. Sci., 5: 65-69.

34. Motozona, Y., Hatano, K., Sugawara, N. and Ishibashi, T. (1998) Effects of dietary chromium picolinate on growth, carcass quality and serum lipids of female broilers. Anim. Sci. Technol., 69: 659-665.

35. Amatya, I.L., Haldar, S. and Ghosh, T.K. (2004) Effects of chromium supplementation from inorganic and organic sources on nutrient utilization, mineral metabolism and meat quality in broiler chickens exposed to natural heat stress. Anim. Sci., 79: 241-253.

36. Li, M.A., Feng, B., Cheng, M.A., Lin, Y. and Ming-Hui, H.U. (2005) Effects of chromium picolinic acid and vitamin E on the performance, carcass quality of cherry valley ducks. $J$. Southwest Univ. Natl., 2: 834-837.

37. Ahmed, N., Haldar, S., Pakhira, M.C. and Ghosh, T.K. (2005) Effects of chromium picolinic acid and vitamin E on the performance, carcass quality of cherry valley ducks. $J$. Southwest Univ. Natl., 2: 834-837.

38. Cupo, M.A. and Donaldson, W.E. (1987) Chromium and vanadium effects on glucose metabolism and lipid synthesis in the chick. Poult. Sci., 66: 120-126.

39. Naghieh, A., Toghyani, M., Gheisari, A.A., Saeed, S.E. and Miranzadeh, H. (2010) Effect of different sources of supplemental chromium on performance and immune responses of broilers chicks. J. Anim. Vet. Adv., 9(2): 354-358.

40. Luciana, M.G.S., Murakmi, A.E., Fernandes, J.I.M., Guerra, R.L.H. and Martins, E.N. (2010) Chromium influence on performance and concentration of lipids in broiler blood plasma. Rev. Bras. Zotecn., 39(4): 808-814.

41. Sahin, K. and Sahin, N. (2002) Effects of chromium picolinate and ascorbic acid dietary supplementation on nitrogen and mineral excretion of laying hens reared in a low ambient temperature $\left(7^{\circ} \mathrm{C}\right)$. Acta Vet. Brno., 71: 183-189.

42. Perai, A.H., Kermanshahi, H., Nassiri, H. and Zarban, A. (2013) Effects of supplemental vitamin C and chromium on metabolic and hormonal responses, antioxidant status, and tonic immobility reactions of transported broiler chickens. Biol. Trace Elem Res., 157: 224-233.

43. Mirfendereski, E. and Jahanian, R. (2015) Effects of dietary organic chromium and Vitamin C supplementation on performance, immune responses, blood metabolites, and stress status of laying hens subjected to high stocking density. Poultr. Sci., 94: 281-288.

44. Ipek, A. and Sahan, U. (2007) Effects of cold stress on broiler performance and ascites susceptibility. Asian Aust. J. Anim. Sci., 19(5): 734-738.

45. Vincent, J.B. (2000) Quest for the molecular mechanism of chromium action and its relationship to diabetes. Nutr. Rev., 58: 67-72.

46. Anderson, R.A. (1994) Stress effects on chromium nutrition of humans and farm animals. In: Lyons, T.P., Lacques, K.A., editors. Biotechnology in the Feed Industry. Nottingham University Press, UK. p267-274.

47. Lien, T.F., Horng, Y.M. and Yang, K.H. (1999) Performance, serum characteristics, carcase traits and lipid metabolism of broilers as affected by supplement of chromium picolinate. Br. Poult. Sci., 40: 357-363.

48. Bakhiet, A.O. and Elbadwi, S.M.A. (2007) Effect of dietary chromium supplementation on the performance and some serum parameters in bovans-type chicks. J. Pharmacol. Toxicol., 2(4): 402-406.

49. Patil, A., Palod, J., Singh, V.S. and Kumar, A. (2008) Effect of graded levels of chromium supplementation on certain serum biochemical parameters in broilers. Indian J. Anim. J. Sci., 78(10): 1149-1152.

50. Aslanian, A., Noori, K., Dizaji, A.A., Shahryar, A., Rouhnavaz, S. and Maheri, N. (2011) Evaluate the effect of chromium methionine on performance and serum metabolite in growing-finishing male broiler. J. Basic Appl. Sci. Res., 1(11): 2442-2448.

51. Bhagat, J., Ahmed, K.A., Tyagi, P., Saxena, M. and Saxena, V.K. (2005) Effects of supplemental chromium on interferon-gamma (IFN-a) mRNA expression in response to Newcastle disease vaccine in broiler chicken. Res. Vet. Sci., 85: 46-51.

52. Kim, S.W., Han, I.K., Choi, Y.J., Kim, Y.H., Shin, I.S. and Chae, B.J. (1995) Effects of chromium picolinate on growth performance, carcass composition and serum traits of broilers fed dietary different levels of crude protein. Asian Aust. J. Anim. Sci., 8: 463-470.

53. Riales, R. and Albrink, J.M. (1981) Effect of chromium chloride supplementation on glucose tolerance and serum lipids including high density lipoprotein of adult men. Am. J. Clin. Nutr., 34: 2670-2678.

54. Lefavi, R.G., Wilson, G.D., Keith, R.E., Blessing, D.L., Hames, C.G. and McMillan, J.L. (1993) Lipid-lowering effect of dietary chromium (III)-nicotinic acid complex in male athletes. Nutr. Res., 13: 239-249.

55. Anderson, R.A., Polansky, M.P., Bryden, N.A. and Canary, J.J. (1991) Supplemental chromium effects on glucose, insulin, glucagon and urinary chromium losses in subjects consuming controlled low-chromium diets. Am. J. Clin. Nutr., 54: 909-916.

56. Kroliczewska, B., Zawadzki, W., Dobrzanski, Z. and Kaczmarek, A. (2004) Changes in selected serum parameters of broiler chicken fed supplemental chromium. J. Anim. Physiol. Nutr., 88: 393-400.

57. Zha, L.Y., Zeng, J.W., Chu, X.W., Mao, L.M. and Luo, H.J. (2009) Efficacy of trivalent chromium on growth performance, carcass characteristics and tissue chromium in heatstressed broiler chicks. J. Sci. Food Agnc., 89: 1782-1786.

58. Navidshad, B., Pirsaraei, Z.A. and Chashnidel, Y. (2010) Effect of dietary chromium polynicotinate supplementation on performance, fat deposition and plasma lipids of broiler chickens. Ital. J. Anim. Sci., 9(1): 9-13.

59. Kapeghian, J.C. and Verlangieri, A.J. (1984) The effects of glucose on ascorbic acid uptake in heart endothelial cells: Possible pathogenesis of diabetic angiopathies. Life Sci., 34: $577-584$.

60. Seaborn, C.D., Cheng, N., Adeleye, B., Owens, F. and Stoecker, B.J. (1994) Chromium and chronic ascorbic acid depletion effects on tissue ascorbate, manganese, and 14C retention from 14C-ascorbate in guinea pigs. Biol. Trace Elem. Res., 41: 279

61. Okada, S., Tsukada, H. and Ohba, H. (1984) Enhancement of nucleolar RNA synthesis by chromium (III) in regenerating rat liver. J. Inorg. Biochem., 21: 113.

62. Anderson, R. (1987) Chromium. In: Mertz, W., editor. Trace Elements in Human and Animal Nutrition. $5^{\text {th }}$ ed., Vol. 1. Ch. 7. Academic Press Inc., San Diego, CA, USA. p225-244.

63. Linder, M.C. (1991) Nutrition and metabolism of the trace elements. In: Nutritional Biochemistry and Metabolism with Clinical Applications. Prentice Hall, New York, USA. p215-276.

64. Gallaher, D.D., Csallany, A.S., Shoeman, D.W. and Olson, J.M. (1993) Diabetes increases excretion of urinary malondehyde cojugates in rats. Lipids, 28: 663-666.

65. Halliwell, B. and Gutteridge, J.M.C. (1989) Lipid peroxidation: A radical chain reaction. In: Free Radicals in Biology and Medicine. $2^{\text {nd }}$ ed. Oxford University Press, New York. p188-218.

66. Tatli Seven, P., Yilmaz, S., Seven, I., Cerci, H.I., Azman, M.A. and Yilmaz, M. (2009) The effect of propolis 
on selected blood indicators and antioxidant enzyme activities in broilers under hot climate. Acta Vet. Brno., 78: 75-83.

67. Tawfeek, S.S., Abdella, K.M. and Youssef, I.M. (2014) The effect of dietary supplementation of some antioxidants on performance, oxidative stress and blood parameters in broilers under natural summer condition. J. World's Poult. Res., 4(1): 10-14.

68. Kutlu, H.R. and Forbes, J.M. (1993) Changes in growth and blood parameters in heat-stressed broiler chicks in response to dietary ascorbic acid. Livest. Prod. Sci., 36: 335-350.

69. McCarty, M.F. (1993) Homologous physiological effects of phenformin and chromium picolinate. Med. Hypotheses, 41: 316-324.

70. Ohba, H., Suzuki, Y. and Ohba, H.J. (1986) Enhancement of ribonucleic acid synthesis by chromium (III)-bound chromatin. J. Inorg. Biochem., 27: 179-188.

71. Ward, T.L., Southern, L.L. and Boleman, S.L. (1993) Effect of dietary chromium picolinate on growth, nitrogen balance and body composition of growing broiler chickens. Poultr. Sci., 73: 37.

72. Lambert, B. and Jacquemin, C. (1979) Inhibition of epinephrine induced lipolysis in isolated white adipocytes of aging rabbits by increased alpha-adrenergic responsiveness. J. Lipid Res., 20: 208-216.

73. Tolmir, N., Pavlovski, Z., Koljajic, V., Mitrovic, S. and Anokic, N. (2005) The effect of different sources and chromium level in ration on broiler breast musculature. Biotechnol. Anim. Husb., 21(5-6): 153-158.

74. Preuss, H.G., Grojec, P.L., Lieberman, S. and Anderson, R.A. (1997) Effects of different chromium compounds on blood pressure and lipid peroxidation in spontaneously hypertensive rats. Clin. Nephrol., 47: 325-330.

75. Ali, M.T., Howlider, M.A., Azad, A.K. and Rahman, M.S. (2010) Vitamin C and electrolyte supplementation to support growth and meat yield of broilers in a hot humid environment. J. Bangladesh Agric. Univ., 8(1): 57-60.

76. Idown, O.M.O., Ajuwon, O.R., Fafiolu, A.O., Oso, A.O. and Akinloye, O.A. (2011) Modulation of cholesterol and copper residue level in muscle and blood serum of finishing broiler chickens fed copper and ascorbic acid supplements. Pak. J. Nutr., 10(8): 781-785.

77. Chae, B.J., Lohakare, J.D. and Choi, J.Y. (2006) Effects of incremental levels of $\alpha$-tocopherol acetate on performance, nutrient digestibility and meat quality of commercial broilers. Asian Aust. J. Anim. Sci., 19(2): 203-208.

78. Sahin, K. and Onderci, M. (2002) Optimal dietary concentrations of Vitamin $\mathrm{C}$ and chromium for alleviating the effect of low ambient temperature on serum insulin, corticosterone and some blood metabolites in laying hens. $J$. Trace Elem. Exp. Med., 15: 151-161.

79. Uyanik, F., Eren, M., Kocaoglu, B. and Sahin, N. (2005) Effects of dietary chromium supplementation on performance, carcass traits, serum metabolites and tissue chromium levels of Japanese quails. Biol. Trace Elem. Res., 103: 187-197.

80. Sahin, N., Sahin, K., Onderci, M., Gursu, M.F., Cikim, G., Vijaya, J. and Kucuk, O. (2005) Chromium picolinate, rather than biotin, alleviates performance and metabolic parameters in heat-stressed quail. Br. Poult. Sci., 46: 457-463.

81. Asmatullah, Asma, A., Latif, A. and Shakoori, A.R. (1999) Effect of hexavalent $\mathrm{Cr}$ on laying capacity, hatchablity of eggs, thickness of egg shell and post hathcing development in Gallus domesticus. Asian Aust. J. Anim. Sci., 12(6): 944-950.

82. Upreti, R.K., Shrivastava, R. and Chaturvedi, U.C. (2004) Gut microflora and toxic metals: Chromium as a model. Indian J. Med. Res., 119: 49-59.

83. Miles, R.D. (2000) Trace minerals and avian embryo development. Cien. Anim. Bras., 2(1): 1-10.

$* * * * * * * *$ 